\title{
Short communication \\ Use of calcium sulphate dihydrate as an alternative to the conventional use of aluminium sulphate in the primary treatment of wastewater
}

\author{
María C Vázquez-Almazán ${ }^{1,2 *}$, Eusebio Ventura1, Enrique Rico ${ }^{1}$ y Mario E Rodríguez-García ${ }^{3}$ \\ ${ }^{1}$ División de Investigación y Posgrado de la Facultad de Ingeniería, Universidad Autónoma de Querétaro, Cerro de las \\ Campanas s/n, Cerro de las Campanas s/n, C.P. 76010, Santiago de Querétaro, Querétaro, México \\ ${ }^{2}$ Área Civil de la Facultad de Ingeniería, Universidad Autónoma de San Luis Potosí, Avenida Salvador Nava s/n, \\ Zona Universitaria, San Luis Potosí, San Luis Potosí, San Luis Potosí, México \\ ${ }^{3}$ Departamento de Nanotecnología, Centro de Física Aplicada y Tecnología Avanzada, Universidad Nacional \\ Autónoma de México, Campus Juriquilla, Querétaro, Querétaro, México
}

\begin{abstract}
The application of calcium sulphate dihydrate $\left(\mathrm{CaSO}_{4}-2 \mathrm{H}_{2} \mathrm{O}\right)$ as a coagulant-flocculant alternative to the conventional use of aluminium sulphate in the primary treatment of wastewater was evaluated using a jar test apparatus. Samples from the State Water Commission (CEA) in Queretaro, México, were collected for the experiments. Turbidity and pH were measured before and after applying the calcium sulphate dihydrate $\left(\mathrm{CaSO}_{4} \cdot 2 \mathrm{H}_{2} \mathrm{O}\right)$. Turbidity readings obtained for the doses of $4 \mathrm{~g} \cdot \ell^{-1}$ of aluminium sulphate varied from 3.91 to 3.87 . The corresponding water $\mathrm{pH}$ was 3.90 , giving the water an acidic character. Use of aluminium sulphate in the clarification of wastewater, thus, has financial and environmental implications due to the need to raise the $\mathrm{pH}$ of the treated water to $6.5-8.5$, the recommended optimum interval for the physical-chemical-biological removal of pollutants. By contrast, calcium sulphate di-hydrate $\left(\mathrm{CaSO}_{4} \cdot 2 \mathrm{H}_{2} \mathrm{O}\right)$ (gypsum) doses of $1,1.5$ and $2 \mathrm{~g} \cdot \ell^{-1}$ resulted in a pH of between 7.04 and 7.51 repeatedly. These findings suggest that the application of calcium sulphate di-hydrate $\left(\mathrm{CaSO}_{4}-2 \mathrm{H}_{2} \mathrm{O}\right)$ as coagulant-flocculant, followed by the process of sedimentation, may be a suitable alternative for the clarification of wastewater. However, the turbidity reported for the same doses was $74.05,80.5$ and $74.5 \mathrm{NTU}$, respectively, well above the international standard of 5 NTU. The effect of gypsum on turbidity warrants further research.
\end{abstract}

Keywords: coagulation-flocculation, jar test, wastewater clarification, turbidity of water

\section{Introduction}

Wastewater treatment systems are pre-emptive systems used to control water pollution reaching surface water bodies such as lakes, rivers and seas (Perez et al., 2004). Water quality is augmented through adequate wastewater treatment, thus having beneficial effects on both the environment and public health, as well as enhancing the potential for re-use (Silva et al., 2008; Tebbutt, 1999).

Water reuse and recycling is a necessary strategy for the sustainability of all of the economic activities which water supports (Dominguez et al., 2003; Ortiz, 2005). However, appropriate treatment is necessary to ensure high efficiency, low cost and protection of the environment in the use of recycled water (Arreguín and Mejia, 2006). The coagulation/flocculation/sedimentation process, also known as advanced primary treatment (APT) (Andia, 2000; Rodriguez et al., 2007), is an effective treatment, but also represents a huge disbursement to be made.

Coagulation/flocculation/sedimentation is a universal method because it eliminates a large number of substances, of various particle weights, at a lower cost than other methods (Andía, 2000; Kaewdannetra et al., 2009; Murrillo, 2009;

\footnotetext{
* To whom all correspondence should be addressed.

政 (444) 8-14-64-29; fax: (444) 8-14-64-29; e-mail: maria.vazquez.almazan@gmail.com Received 9 May 2011; accepted in revised form 18 September 2012.
}

Rodríguez et al., 2007). Turbidity is considered an important parameter for evaluating the quality of a water body. It indicates quality in terms of concentration of colloidal particles (Arboleda, 2000; Harris, 2007). The higher the particle count, the more turbid the water is (Yan et al., 2008). These colloidal particles have, in most cases, a negative surface charge, causing repulsion between them (Chen, 2004). This phenomenon is known as the diffuse double layer and it prevents the agglomeration of these particles (Haydar and Anwar, 2009). Therefore, it is important to promote the destabilisation of the particles by adding cationic coagulants (Simina et al., 2009). The later stages of water treatment depend largely on the success of the coagulation-flocculation-sedimentation process (Díaz et al., 2007; Kaewdannetra, et al., 2009).

Aluminium sulphate is conventionally used for the coagulation-flocculation process in primary treatment of wastewater. Aluminium is considered a toxic element for plants and animals. Therefore, its presence in soils and aquatic systems can cause negative effects (Delhaize and Ryan, 1995; Rapp and Bishop, 2009). Increased acidity in soils is associated with toxic levels of aluminium in plants (Lidon and Barreiro, 2002; Mossor-Pietraszewska, 2001; Pacala, et al., 2009; Rotter and Furlani, 2005). Therefore, there is interest in developing the use of alternative, new coagulants without this impact, since the benefits outweigh, in many cases, the costs of using them (Murrillo, 2009; Qui, et al., 2009). It is, therefore, necessary to evaluate the performance of other coagulants in the clarification of wastewater. 
This study evaluated the use of calcium sulphate dihydrate $\left(\mathrm{CaSO}_{4} \cdot 2 \mathrm{H}_{2} \mathrm{O}\right)$ (gypsum) as an alternative to aluminium sulphate in wastewater clarification, with the option to provide treated reused water for agricultural purposes, amongst other options.

It is important to emphasize that there are no antecedents for the use of calcium sulphate as a coagulant-flocculant. Hence, this study aimed to demonstrate the possibilities of its application as such, without changing the original characteristics of the sample waters and taking into account the variables which directly influence the success of the primary treatment process, i.e. $\mathrm{pH}$, mixing speed, and retention time.

\section{Materials and methods}

\section{Sample collection and processing}

Water samples were collected from a wastewater treatment plant located and operated by the State Water Commission (CEA) in the Mexican city of Queretaro (20 $35^{\prime} 25.74^{\prime \prime} \mathrm{N}$, $100^{\circ} 24$ '53.60" W; $1813 \mathrm{~m}$ amsl). Water samples were collected in $19 \ell$ plastic bottles. They were immediately transported in a water cooler at $4^{\circ} \mathrm{C}$ to the laboratory. The samples were collected at a single point with 4 replications.

\section{Origin of calcium sulphate dihydrate (gypsum) and its characteristics}

Calcium sulphate dihydrate (gypsum) $\left(\mathrm{CaSO}_{4} 2 \mathrm{H}_{2} \mathrm{O}\right)$ was provided by the Yesera Monterrey, S.A. The product is known commercially as 'maximum agricultural gypsum' and comes in a powder form. The technical specifications are presented in Table 1.

\begin{tabular}{|l|l|}
\hline \multicolumn{2}{|c|}{ Table $\mathbf{1}$} \\
Technical specification of $\mathrm{CaSO}_{4} \cdot \mathbf{2} \mathbf{H}_{2} \mathbf{O}$ used \\
\hline CaSO $_{4} \cdot \mathbf{2} \mathrm{H}_{2} \mathbf{O}$ powder & $\begin{array}{l}\text { Technical } \\
\text { specification }\end{array}$ \\
\hline Particle size per cent retained on screen 100 & $18-20$ \\
\hline Per cent purity of $\mathrm{CaSO}_{4} \cdot 2 \mathrm{H}_{2} \mathrm{O}$ & $90-96$ \\
\hline Per cent calcium $(\mathrm{Ca})$ & $19.5-21.9$ \\
\hline Per cent sulphur $(\mathrm{S})$ & $14.9-17.5$ \\
\hline
\end{tabular}

\section{Variables for the characterisation of sample water}

The study employed 3 response variables:

- potential of hydrogen $(\mathrm{pH})$,

- electrical conductivity (EC), and

- turbidity.

These 3 variables were measured in the raw wastewater before treatment was applied. Hydrogen ion concentration is an important parameter for both natural and sewage waters because it has an influence on the effluent conditions, which could affect both the flora and fauna of the receiving water body. The final value of this parameter is governed by regulation of the maximum allowable discharges for wastewater going into sewers or receiving bodies. Electrical conductivity is also of great importance as it indicates the degree of mineralisation present in the wastewater. Turbidity is useful as an indicator of water quality and plays an important role in the performance of wastewater treatment plants; turbidity is an important consideration in water for human consumption and

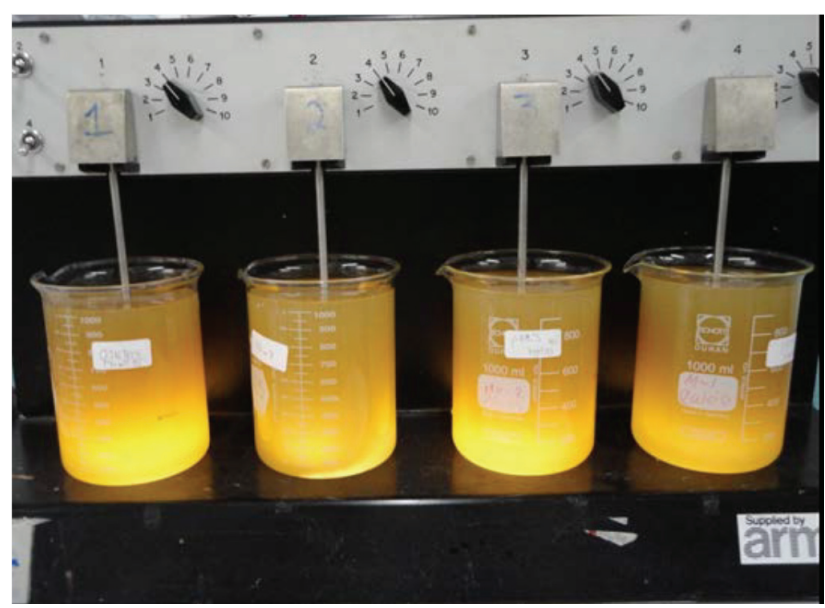

Figure 1

The jar test apparatus

for use in food processing and beverage industries, amongst others. Turbidity values are used to determine the degree of treatment required by a raw water source, its filterability and, consequently, the most suitable filtration rate, and the effectiveness of the processes of coagulation-flocculation, sedimentation and final filtration. EC and $\mathrm{pH}$ were measured with the Horiba D-54 potentiometer. The sample water was placed into a 1000 $\mathrm{m} \ell$ beaker for each of the 4 replicates, and the $\mathrm{pH}$ and $\mathrm{EC}(\mu \mathrm{S} /$ $\mathrm{cm}$ ) read using the respective electrodes.

Turbidity was measured using a Hach 4000 U spectrophotometer Program 1870. A sub-sample of $5 \mathrm{~m}^{3}$ was taken from the upper part of the sample in order to avoid sampling solids that had already settled.

\section{Experimental design}

The coagulants-flocculants used in this experiments were: calcium sulphate dihydrate $\left(\mathrm{Ca}\left(\mathrm{SO}_{4}\right) \cdot 2 \mathrm{H}_{2} \mathrm{O}\right)$, a divalent compound, and aluminium sulphate with 18 molecules of water $\left(\left(\mathrm{Al}_{2}\left(\mathrm{SO}_{4}\right)_{3}\right) \cdot 18 \mathrm{H}_{2} \mathrm{O}\right)$, a trivalent compound. The doses of the 2 coagulant-flocculants for the treatment were $0.00,0.50,1.00$, $1.50,2.00,2.50,3.00,3.50$ and $4.00 \mathrm{~g} \cdot \ell^{-1}$ added in dry powder state. These doses were established after performing an initial test to determine the dose at which coagulation started.

\section{Jar test apparatus}

The sedimentation equipment (jar test apparatus; Fig. 1) has 4 units with detachable stainless steel flat propellers used as agitators. These simulate the mixing and settling conditions in a clarification plant. When the experiment is conducted in the laboratory, there is the advantage of being able to make 4 runs simultaneously with the help of the jar test apparatus. The engine has an electronic speed control from 0 to $100 \mathrm{r} \cdot \mathrm{min}^{-1}$ and the tachometer is mechanical. It operates on $120 \mathrm{~V}$ and includes a fluorescent lamp base and 4 Armfield brand $1 \ell$ cups.

\section{Jar test methodology}

After the characterisation of raw water, the standard doses of coagulants-flocculants were applied using the jar test apparatus, with the aim of defining the following parameters: raw water quality, rates of coagulation and flocculation, retention times, and $\mathrm{pH}$ adjustment. 
The procedure used was as follows:

- The 4 beakers were filled with $1000 \mathrm{~m} \ell$ of raw water which was pre-measured in a test tube.

- The beakers were labelled with the corresponding dose as well as the coagulant-flocculants applied; then the steel blades were placed in each beaker.

- The device was turned on, along with the lamp, and the paddles were run at $100 \mathrm{r} \cdot \mathrm{min}^{-1}$ (maximum speed for the jar apparatus), with the purpose of homogenising the sample for $60 \mathrm{~s}$.

- After this time, the coagulant was added with the doses previously assigned. It was applied in the centre of the pallet where the vortex is formed, to ensure maximum dissemination and allowing the process to continue for another $60 \mathrm{~s}$ at the maximum speed. It is at this point that coagulation occurs.

- After this time, the mixing speed was slowed to $40 \mathrm{r} \cdot \mathrm{min}^{-1}$ for approx. $20 \mathrm{~min}$. It is at this point that flocculation occurs.

- After this period, the device was switched off. Each of the blades was carefully removed and the samples left to sit for 15 min - the settling time for this experiment.

- Finally, the response parameters ( $\mathrm{pH}, \mathrm{EC}$ and turbidity) were measured.

\section{Statistical analysis}

One-way ANOVA $(p<0.05)$ was applied to determine the dependence between dose and response variable for each coagulant-flocculant and dosage used.

\section{Results}

\section{Jar test}

The results of the jar test with the respective doses for each of the treatments are shown in Table 2 and graphically presented in Figs. 2, 3 and 4.

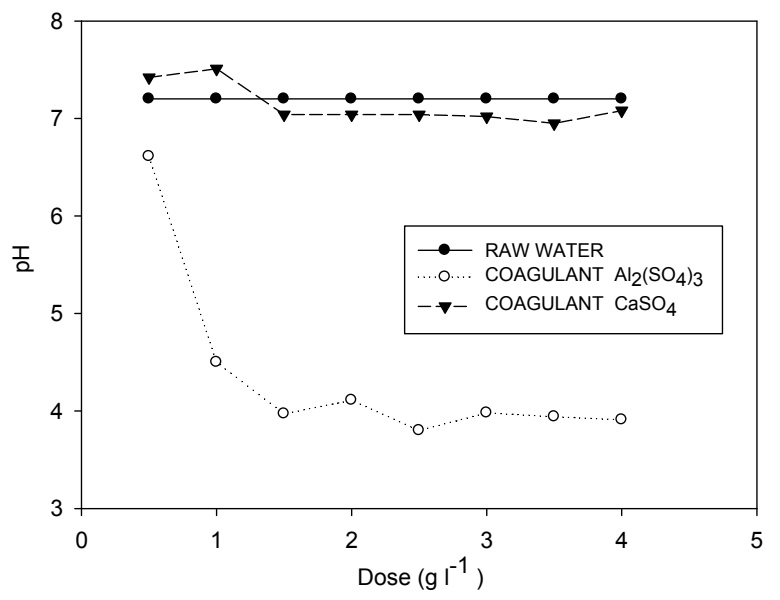

Figure 2 (above)

Variation of $\mathrm{pH}$ with respect to the applied coagulant dose

Figure 3 (top right)

Variation of EC with respect to the applied coagulant dose

Figure 4 (bottom right)

Variation of turbidity with respect to the applied coagulant dose

\begin{tabular}{|c|c|c|c|c|c|c|}
\hline \multicolumn{7}{|c|}{$\begin{array}{c}\text { Table } 2 \\
\text { EC and turbidity after treatments }\end{array}$} \\
\hline Doses & \multicolumn{3}{|c|}{$\mathrm{CaSO}_{4}$} & \multicolumn{3}{|c|}{$\mathrm{Al}_{2}\left(\mathrm{SO}_{4}\right)_{3}$} \\
\hline$\left(g \cdot \ell^{-1}\right)$ & Mean & SD & Tukey & Mean & SD & Tukey \\
\hline \multicolumn{7}{|c|}{$\mathrm{EC}\left(\mu \mathrm{S} \cdot \mathbf{c m}^{-1}\right)$} \\
\hline 0.00 & 131.63 & 1.70 & I & 131.63 & 1.70 & hi \\
\hline 0.50 & 145.13 & 1.65 & $\mathrm{~h}$ & 131.90 & 0.18 & $\mathrm{~h}$ \\
\hline 1.00 & 189.10 & 0.08 & $\mathrm{~g}$ & 143.35 & 0.13 & $\mathrm{~g}$ \\
\hline 1.50 & 202.01 & 0.15 & $\mathrm{f}$ & 160.73 & 0.17 & $\mathrm{f}$ \\
\hline 2.00 & 251.00 & 0.82 & $\mathrm{e}$ & 186.08 & 0.10 & $\mathrm{e}$ \\
\hline 2.50 & 261.00 & 1.63 & $\mathrm{~d}$ & 187.98 & 0.15 & $\mathrm{~d}$ \\
\hline 3.00 & 284.00 & 1.41 & $\mathrm{c}$ & 220.98 & 0.05 & $\mathrm{c}$ \\
\hline 3.50 & 311.00 & 0.08 & $\mathrm{a}$ & 235.00 & 0.82 & $\mathrm{c}$ \\
\hline 4.00 & 308.98 & 1.31 & $a b$ & 240.00 & 0.87 & $\mathrm{c}$ \\
\hline \multicolumn{7}{|c|}{ Turbidity (NTU) } \\
\hline 0.00 & 63.50 & 0.08 & $\mathrm{e}$ & 63.50 & 0.08 & $\mathrm{a}$ \\
\hline 0.50 & 74.50 & 0.08 & $\mathrm{~b}$ & 2.94 & 0.02 & $\mathrm{~h}$ \\
\hline 1.00 & 74.05 & 0.00 & $\mathrm{~b}$ & 7.27 & 0.01 & $\mathrm{~d}$ \\
\hline 1.50 & 80.50 & 0.04 & $\mathrm{a}$ & 4.88 & 0.00 & $\mathrm{f}$ \\
\hline 2.00 & 74.50 & 0.01 & $\mathrm{~b}$ & 7.19 & 0.00 & $\mathrm{e}$ \\
\hline 2.50 & 72.50 & 0.01 & $\mathrm{c}$ & 9.82 & 0.00 & $\mathrm{~b}$ \\
\hline 3.00 & 67.50 & 0.52 & $\mathrm{~d}$ & 7.27 & 0.00 & $\mathrm{~d}$ \\
\hline 3.50 & 56.50 & 0.08 & $\mathrm{~g}$ & 8.40 & 0.00 & $\mathrm{c}$ \\
\hline 4.00 & 62.20 & 0.20 & $\mathrm{f}$ & 3.87 & 0.00 & $\mathrm{~g}$ \\
\hline
\end{tabular}

SD: Standard deviation.

Values followed by the same letter for each parameter evaluated are not significantly different. The comparison of mean values was performed with a confidence level of $95 \%$, as determined by Tukey's test.
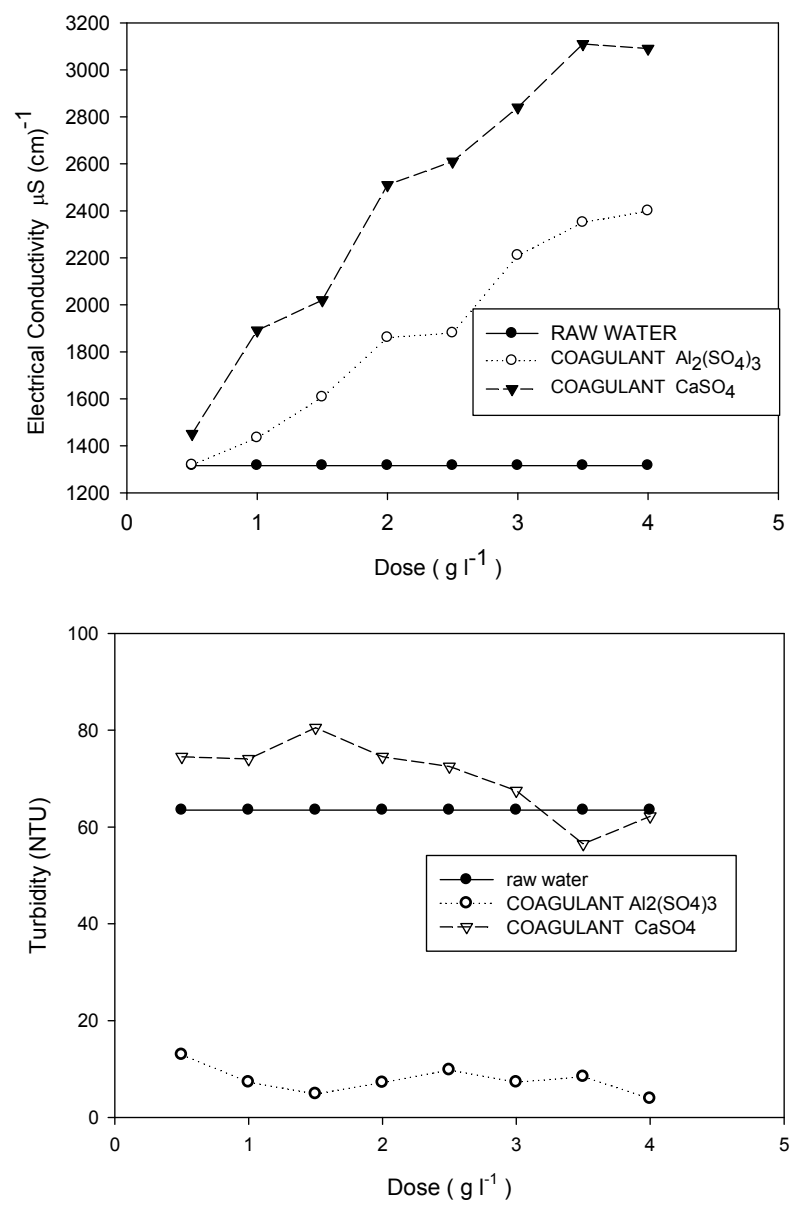


\begin{tabular}{|l|c|c|c|c|c|c|}
\hline \multicolumn{7}{|c|}{ Table 3 } \\
\hline $\begin{array}{l}\text { Coefficient of variation (CV) } \\
\text { flocculant- }\end{array}$ & \multicolumn{3}{|c|}{ CaSO $_{4} \cdot 2 \mathrm{H}_{2} \mathrm{O}$} & \multicolumn{3}{c|}{$\mathrm{Al}_{2}\left(\mathrm{SO}_{4}\right)_{3} \cdot 18 \mathrm{H}_{2} \mathrm{O}$} \\
\hline $\begin{array}{l}\text { Dispersion } \\
\text { measures }\end{array}$ & Mean & SD & $\mathbf{C V} \%$ & Mean & SD & CV \% \\
\hline EC & 231.54 & 60.50 & 26.13 & 181.96 & 42.92 & 23.59 \\
\hline Turbidity & 69.53 & 7.61 & 10.94 & 12.79 & 19.14 & 149.62 \\
\hline
\end{tabular}

\section{Discussion}

\section{Potential of hydrogen}

$\mathrm{pH}$ is often considered to be the most important water quality parameter, because certain chemical processes only take place at a specific $\mathrm{pH}$. Table 2 shows the variation of $\mathrm{pH}$ with respect to the incremental doses of coagulants used (Fig. 2). For $\mathrm{CaSO}_{4} \cdot 2 \mathrm{H}_{2} \mathrm{O}$, Fig. 2 shows that a neutral character of the solution was maintained. For the $1 \mathrm{~g} \cdot \ell^{-1}$ dose, a maximum value of 7.51 was obtained and for the dose of $3.5 \mathrm{~g} \cdot \ell^{-1}$ the corresponding $\mathrm{pH}$ was 6.9.

For addition of aluminium sulphate, the higher the dose of $\mathrm{Al}_{2}\left(\mathrm{SO}_{4}\right)_{3}$, the lower the $\mathrm{pH}$ becomes. It is important to note the effect of aluminium on $\mathrm{pH}$. This implies a considerable reduction in the $\mathrm{pH}$ of the raw treated water when aluminium sulphate is used. The minimum dose also gave an acidic character to the water. The raw water had the highest $\mathrm{pH}$ and the treated water that received a dose of $2.5 \mathrm{~g} \cdot \ell^{-1}$ had the lowest $\mathrm{pH}$, of 3.79 .

Comparing the $\mathrm{pH}$ values obtained to the maximum/ minimum limits of the norm NOM-001-SEMARNAT-1996 (SEMARNAT, 2003), it can be seen that application of aluminium sulphate results in $\mathrm{pH}$ readings outside the standard ranges established for Mexico (6.5-8.5). The likely chemical process involved is as follows: The raw water had a neutral $\mathrm{pH}$; by adding aluminium sulphate it was hydrolysed to form a colloidal aluminium hydroxide and an equivalent amount of sulphuric acid in accordance with the following chemical equation:

$$
\mathrm{Al}_{2}\left(\mathrm{SO}_{4}\right)_{3}+6 \mathrm{H}_{2} \mathrm{O}=2 \mathrm{Al}(\mathrm{OH})_{3}+3 \mathrm{H}_{2} \mathrm{SO}_{4}
$$

When using commercial aluminium sulphate, it is found that $1 \mathrm{~g} \cdot \ell^{-1}$ of aluminium sulphate destroys $0.5 \mathrm{~g} \cdot \ell^{-1}$ of alkalinity produced by $0.44 \mathrm{~g} \cdot \ell^{-1}$ of carbon dioxide (Tebbut, 1999).

With the application of coagulant-flocculant $\mathrm{CaSO}_{4} \cdot 2 \mathrm{H}_{2} \mathrm{O}$, the $\mathrm{pH}$ started at 7.2, and showed fluctuations between 6.96 and 7.51. Therefore, the $\mathrm{pH}$ variation with addition of this coagulant was minimal, and within the regulated range for treated effluent in Mexico. The resulting neutral $\mathrm{pH}$ of the treated water is an advantage for reuse of the water. The ranges were within the values established by the regulations.

It is important to note from Tables 2 and 3 that for both flocculant-coagulants the $\mathrm{pH}$ does not differ significantly between the different doses tested.

\section{Electrical conductivity}

Table 2 shows that increasing the dose of both coagulants results in an increase in electrical conductivity (Fig. 3 and Table 3), and the coefficients of variation are similar for both coagulants $\left(26.13 \%\right.$ for $\mathrm{CaSO}_{4}$ and $23.59 \%$ for $\left.\mathrm{Al}_{2}\left(\mathrm{SO}_{4}\right)_{3}\right)$. Martínez (2004) found that at $\mathrm{pH}$ values below 5.5 the electrical conductivity increases, producing an acidic character in the water, making it impractical for reuse in agriculture.
The values of EC for both treatments are below $0.7 \mathrm{dS} \cdot \mathrm{m}^{-1}$ (Table 2) and, therefore, within the recommended value for treated wastewater (Tchobanoglous and Burton, 2000) used in irrigation systems.

\section{Turbidity}

With respect to turbidity removal, the results for all doses of calcium sulphate di-hydrate $\left(\mathrm{CaSO}_{4} \cdot 2 \mathrm{H}_{2} \mathrm{O}\right)$ tested were not encouraging. From Table 2 , the original turbidity of the raw water was 63.5 NTU and the highest reduction in turbidity by calcium sulphate di-hydrate was achieved by a dose of $3.5 \mathrm{~g} \cdot \ell^{-1}$ (final turbidity of $56.5 \mathrm{NTU}$; removal of $11.02 \%$ turbidity). Use of aluminium sulphate, by contrast, resulted in a clearance rate of $93.91 \%$ for a dose of $4 \mathrm{~g} \cdot \ell^{-1}$; (final turbidity of $\left.3.87 \mathrm{NTU}\right)$. The turbidity results achieved for the different doses of the two coagulants studied were significantly different in most cases (Table 2).

Table 3 presents the coefficients of variation around the mean of the results for all doses of each coagulant. The coefficients of variation for turbidity were $10.94 \%$ and $149.62 \%$, for calcium sulphate and aluminium sulphate, respectively. It is important to note the low cost of producing calcium sulphate di-hydrate $\left(\mathrm{CaSO}_{4} \cdot 2 \mathrm{H}_{2} \mathrm{O}\right)$. Gypsum retails at a price of USD0.060 per kg, compared to aluminium sulphate at USD $\$ 0.45$ per $\mathrm{kg}$, a difference of $86.67 \%$ (of the price of aluminium sulphate).

This study was a first step in assessing the suitability of calcium sulphate di-hydrate as coagulant-flocculant in the primary treatment of wastewater. Due to the complexity of the coagulation-flocculation process, further investigation and the refinement of various elements is required.

\section{Conclusions}

The alternative use of calcium sulphate di-hydrate $\left(\mathrm{CaSO}_{4} \cdot 2 \mathrm{H}_{2} \mathrm{O}\right)$ as a coagulant-flocculant in the primary treatment of wastewater may be economically and environmentally beneficial. However, it is well known that an 'at-source' wastewater treatment plant represents a complex system. Therefore, more research is needed to understand the coagulation-flocculation phenomena, and to establish the specific isoelectric point for calcium sulphate di-hydrate $\left(\mathrm{CaSO}_{4} \cdot 2 \mathrm{H}_{2} \mathrm{O}\right)$, i.e. the optimum $\mathrm{pH}$ for coagulation-flocculation.

\section{Acknowledgements}

The authors are very grateful for the help of the people who provided full support to this research, especially to the Universidad Autónoma de San Luis Potosí for providing access to the sanitation facilities section of the laboratory in the Civil Engineering Area, headed by Reyna Maria Pérez Salinas. They are also grateful to Lucio Gallegos Juárez, engineer, for his collaboration in editing the English language. This project was carried out by the $\mathrm{Ph}$.D. programme in Engineering with the support of CONACYT as part of the training offered by the Universidad Autónoma de Querétaro.

\section{References}

ANDÍA CY (2000) Tratamiento de Agua Coagulación y Floculación. SEDAPAL. Evaluación de Planta y Desarrollo Tecnológico. Lima ARBOLEDA VJ (2000) Theory and Practice of Water Purification. McGraw-Hill, Santa Fé de Bogotá, Colombia. Vol. 1 (3) 1-739 (in Spanish). 
ARREGUÍN CFI and MEJÍA ME (2006) Water Quality Management in Mexico. In: Biswas AK and Tortajada C (eds.) Water Resources Development and Management. Springer, Berlin \& Heidelberg. 119-136.

CHEN G (2004) Electrochemical technologies in wastewater treatment. Sep. Purif. Technol. 38 (1) 11-41.

DELHAIZE E and RYAN RP (1995) Aluminium toxicity and tolerance in plants. Plant Physiol. 107 315-321.

DÍAZ MWH, GONZAGA LB and CONTRERAS CN (2007) Determinación del Coagulante que permita la máxima remoción de Fosfátos en Agua Cruda del Rio Otún. Universidad Tecnológica de Pereira 13 (34) 607-612.DOMÍNGUEZ ME, CARRILLO CHA, ORTEGA A and OROZCO EMT (2003) Wastewater reuse in Valsequillo agricultural area, Mexico: Environmental impact on groundwater. Water Air Soil Pollut. 155 251-267.

HARRIS DC (2007) Quantitative Chemical Analysis (6 ${ }^{\text {th }}$ edn.). W.H. Freeman and Company, New York \& Basingstoke. 1-744.

HAYDAR S and ANWAE AJ (2009) Coagulation-flocculation studies of tannery wastewater using cationic polymers as a replacement of metal salts. Water Sci. Technol. 59 (2) 381-391.

KAEWDANNETRA P, GARCÍA GFJ, JAMES AE and CHIU TY (2009) Influence of $\mathrm{pH}$ and $\mathrm{Al}_{2}\left(\mathrm{SO}_{3}\right)_{3}$ on the stability of whey suspensions. Sep. Purif. Technol. 67 364-368.

LIDON FC and BARREIRO MDG (2002) An overview into aluminium toxicity in maize. Bulg. J. Plant Physiol. 28 96-112.

MARTÍNEZ SX (2004) ¿Es el Control de la Conductividad un Parámetro adecuado para la gestión de la Fertirrigación? Publicado en Riegos y Drenajes 21 (139/Nov-Dec) 62-65.

MOSSOR-PIETRASZEWSKA T (2001) Effect of aluminium on plant growth and metabolism. Acta Biochim. Polonica. 48 (3) 673-686.

MURILLO JM (2009) Turbidez y sólidos en suspensión de las aguas de escorrentía susceptibles de ser utilizadas en la recarga artificial del acuífero granular profundo subyacente a la ciudad de San Luis Potosí (México). Boletin Geologico y Minero 120 (2) 169-184.

ORTIZ MEJ (2005) La experiencia de Holanda y Alemania en el uso de cargos por vertimientos de aguas residuales como instrumento para el control de la contaminación hídrica. Elementos para decidir los parámetros a ser tenidos en consideración. Economía y Desarrollo 4 (1) 55-87.

PACALA A, VLAICU I and RADOVAN C (2009) Application of several aluminium prehydrolysed coagulants in surface water treatment for potabilization. Environ. Eng. Manage. J. 8 (6) 1371-1376.

PÉREZ N, MARAÑON A, BERMÚDEZ RC, AGUILERA I, CUMBÁ F, ABALOS A (2004) Caracterización de las aguas residuales de la refinería "Hermanos Díaz". Revista Cubana de Química 16 (1) 53-60.

QUI Z-M, JIANG, WEN-TIAN, HE, ZONG.JIAN (2009) Posttreatment of banknote printing wastewater using polysilicate ferroaluminium sulphate (PSFA). J. Hazardous Mater. 166 740-745.

RAPP L and BISHOP K (2009) Surface water acidification and critical loads: exploring the F-factor. Hydrol. Earth Syst. Sci. 48 (3) $673-686$.

RODRÍGUEZ JPM, LUGO IPU, ROJAS AVC and MALAVER CC (2007) Evaluation of the coagulation process for designing a water treatment plant. Threshold Scientific. Manuela Beltran University Foundation, Bogota. 8-16 (in Spanish).

ROTTER MA and FURLANI PR (2005) Tolerance to aluminium toxicity by tropical leguminous plants used as cover crops. Braz. Arch. Biol. Technol. 48 (2) 309-317.

SEMARNAT (SECRETARY OF ENVIRONMENT AND NATURAL RESOURCES, MEXICO) (2003) NOM-001-SEMARNAT-1996, establishing the maximum pollution limits for municipal and industrial wastewater discharges to water bodies. Official Journal of the Federation, 23 April, 2003.

SILVA J, TORRES P and MADERA C (2008) Reuso de aguas residuales domésticas en agricultura. Una Revisión Agronomía Colombiana 26 (2) 347-359.

SIMINA SD, COSTACHE C, RUXANDU V, BALAS M and STEFAN M (2009) Comparative study on surface water treatment using aluminium sulphate and polyaluminium chlorides as coagulant reagents. Environ. Eng. Manage. J. 8 (4) 859-863.

TEBBUTT THV (1999) Fundamentos de control de la calidad del agua. Editorial Limusa, S.A de C.V. CANIEM NÚM. 121, 5-239.

TCHOBANOGLOUS G and BURTON FL (eds) (2000) Wastewater Engineering. Treatment, Disposal, Reuse. Metcalf \& Eddy Inc. McGraw-Hill, New York (in Spanish).

YAN M, WANG D, NI J, QU J, YAN Y and CHOW WK (2008) Effect of polyaluminium chloride on enhanced softening for the typical organic-polluted high hardness North-China surface waters. Sep. Purif. Technol. 62 401-406. 
http://dx.doi.org/10.4314/wsa.v38i5.22 Available on website http://www.wrc.org.za

ISSN 0378-4738 (Print) $=$ Water SA Vol. 38 No. 5 October 2012 ISSN 1816-7950 (On-line) $=$ Water SA Vol. 38 No. 5 October 2012 